\title{
KEBERADAAN E. COLI DALAM ES BATU PADA JAJANAN ANAK SEKOLAH DASAR
}

\author{
Anisa Nisviarisna, Mila Mardotillah, Tuti Surtimanah \\ Ilmu Kesehatan Masyarakat STIKes Dharma Husada Bandung. Indonesia. \\ Jl. Terusan Jakarta No.71 - 75, Cicaheum, Kiaracondong, Kota Bandung, Jawa Barat 40282 \\ Email : anisanisviarisna@gmail.com
}

\begin{abstract}
Existence of e.coli's pattern in ice cubes on paddler at primary school. E.coli is a large and diverse group of bacteria found in the human intestinal tract. Transmission of e.coli into a food product may be through fecal contamination due to lack of hand washing after defecation, additionally processed foods can be contaminated by e.coli from equipment that has not been cleaned and reused for the next food product one is ice cubes. This research aims to know the existence of and tracing the cause of e.coli in ice cubes on paddler at primary school in Subdistrict Antapani Bandung. Research carried out in 13 elementary school in Antapani 2018, is the type of qualitative research by conducting interviews to informant confirmed by laboratory test. Raw material for the manufacture of ice cubes using water of PDAM and water refill. This study stated that the water resources (SAB), trash and a work shirt is already $100 \%$ in state eligible, while only $70 \%$ to SPAL that use septic tank and 30\% drain into the river, there are 10\% that do the CTPS and 0\% for the use of the APD. Observationally only dishcloth that reach 100\%, the rest should be upgraded again. In terms of sanitation especially storage of ice cubes, there are $80 \%$ and $20 \%$ still do not qualify. Laboratory results state that all negative samples. Laboratory result that Ice cubes in producers and paddlers do not contain E. coli. Paddler is not yet eligible sanitation as a whole. Therefore, it is expected to pay more attention to cleanliness of the companionship.
\end{abstract}

Keywords : E.coli, Ice Cubes, paddler at Primary School

\begin{abstract}
Abstrak: Keberadaan E. coli dalam Es Batu pada jajanan anak Sekolah Dasar. E.coli merupakan kelompok bakteri besar dan beragam, e.coli ditemukan di saluran usus manusia. Penularan E.coli ke produk makanan dapat melalui kontaminasi tinja akibat mencuci tangan tidak bersih setelah buang air besar, selain itu makanan olahan bisa terkontaminasi E.coli dari peralatan yang belum dibersihkan dan digunakan kembali untuk produk makanan selanjutnya salah satunya adalah es batu. Penelitian ini bertujuan untuk mengetahui keberadaan dan menelusuri penyebab E.coli dalam es batu pada jajanan anak Sekolah Dasar di Wilayah Kecamatan Antapani Kota Bandung. Penelitian dilaksanaan di 13 Sekolah Dasar di wilayah Kecamatan Antapani tahun 2018, merupakan jenis penelitian kualitatif dengan melakukan wawancara kepada informan diperkuat oleh uji laboratorium. Bahan baku pembuatan es batu menggunakan air PDAM dan air minum isi ulang. Penelitian menyatakan bahwa SAB, sampah dan baju kerja sudah $100 \%$ dalam keadaan memenuhi syarat, sementara untuk SPAL hanya $70 \%$ yang menggunakan septictank dan 30\% mengalirkan ke sungai, terdapat 10\% yang melakukan CTPS dan $0 \%$ untuk penggunaan APD. Berdasarkan hasil observasi hanya lap yang mencapai angka $100 \%$, sisanya harus lebih ditingkatkan lagi. Dari segi sanitasi terutama tempat penyimpanan es batu, terdapat $80 \%$ memenuhi syarat dan $20 \%$ masih belum memenuhi syarat. Hasil laboratorium menyatakan bahwa semua sampel negatif. Es batu di produsen dan pedagang tidak mengandung E. coli dan secara keseluruhan sanitasi pedagang belum memenuhi syarat. Oleh karena itu, diharapkan untuk lebih memperhatikan kebersihan dagangannya.
\end{abstract}

Kata Kunci: E.coli, Es Batu, Jajanan Sekolah Dasar 


\section{PENDAHULUAN}

Air sangat penting untuk menopang kehidupan dan harus tersedia untuk semua orang. Persediaan air yang memuaskan bagi masyarakat seperti air yang memadai, aman, mudah di akses dan memenuhi syarat, terutama untuk air minum. Air minum yang aman adalah air minum yang tidak memiliki risiko kesehatan yang signifikan selama masa konsumsi[1]. Dalam tubuh manusia $70 \%$ terdiri dari air. Jika tubuh kehilangan air sebesar $5 \%$ dari berat badan maka keadaan ini telah membahayakan kehidupan orang tersebut[2].

Di kebanyakan negara memiliki risiko utama terhadap kesehatan manusia yang terkait dengan konsumsi air disebabkan oleh mikrobiologis[3]. Mengkonsumsi air minum dibedakan menjadi 2, ada yang dikonsumsi secara langsung dan ada yang melewati proses pengolahan terlebih dahulu sebelum di konsumsi. Salah satu proses pengolahan air minum yaitu dengan melakukan proses pembekuan, dimana terjadi perubahan air menjadi es ${ }^{[4]}$. Secara umum air yang dikatakan layak minum jika air tersebut jernih, tidak berasa, tidak berbau dan tidak mengandung zat-zat dan atau organisme berbahaya. Namun hal tersebut belum cukup dikatakan sebagai air yang layak minum jika terjadi pencemaran pada air minum, baik pencemaran secara fisik, kimia dan bakteriologis ${ }^{[5]}$.

Pencemaran air minum yang sering terjadi yaitu pencemaran yang disebabkan oleh bakteriologis seperti E.coli. Berdasarkan penelitian Jasmin yang dilakukan di Florida Selatan pada tahun 2006, bahwa $70 \%$ es batu pada restoran siap saji lebih memiliki banyak kuman dibandingkan air toilet. Hasil tes es batu tersebut juga positif mengandung bakteri E.coli yang biasanya terdapat dari sisa air pembuangan yang menyebabkan timbulnya beberapa penyakit[6].

Penelitian yang dilakukan di Tembalang, Semarang pada tahun 2016 menyatakan bahwa sebanyak $50 \%$ es batu yang digunakan para pedagang warung makan di Tembalang masih terdeteksi keberadaan E.coli pada es batu yang digunakan, sehingga tidak memenuhi syarat untuk dikonsumsi. Penelitian Azzahra, dkk menunjukkan bahwa terdapat 2 jenis dari 19 sampel jajanan terkontaminasi E. coli. Penelitian Lestari, dkk menunjukkan $52 \%$ jus buah terkontaminasi E. coli. Hasil yang ham[ir sama ditunjukkan oleh hasil penelitian Paramita, dkk bahwa terdapat cemaran E. coli terhadap 19 sampel dari 52 sampel yang diteliti[7].

Hampir semua anak sekolah mempunyai kebiasaan jajan,baik itu dari tingkat SD, SMP, SMA maupun yang berada di Universitas. Kebiasaan jajan ini yang menjadi faktor utama bagi anak sekolah untuk mendapatkan makanan yang sesuai dengan keinginan. Di lingkungan sekolah banyak sekali ditemukan makanan jajanan baik oleh kantin maupun pedagang kaki lima yang umumnya rutin dikonsumsi oleh anak usia sekolah. Anak Sekolah Dasar merupakan usia yang paling rentan terserang penyakit akibat jajanan, karena belum memikirkan masalah kebersihan dari jajanan yang dibeli terhadap kesehatan. Berdasarkan data Kota Bandung tahun 2012 terdapat sebanyak 403.133 anak dengan usia 6-12 tahun, dimana usia tersebut mayoritasnya merupakan usia anak Sekolah Dasar. Anak Sekolah Dasar sering membeli jajanan tanpa memikirkan kesehatan, di Kota Bandung tahun 2012 dilaporkan sebanyak 70.094 kasus diare terutama pada anak, angka ini menurun dibandingkan tahun 2011 sebesar 77.829 kasus. Akan tetapi angka tersebut masih tinggi, sehingga masih diperlukan pencegahan dan penanganan diare pada anak ${ }^{8]}$.

Kecamatan Antapani merupakan bagian dari Kota Bandung, sebuah wilayah pemekaran, mayoritas lingkungan Antapani adalah komplek perumahan. Kecamatan Antapani memiliki satu kendala yaitu sulitnya akses untuk mendapatkan air bersih, dengan hal tersebut kemungkinan air yang digunakan pedagang untuk membuat hasil produksinya bisa berasal dari air yang tidak bersih, seperti halnya dalam pembuatan es batu. Es batu sering di konsumsi anak-anak terutama yang masih duduk di Sekolah Dasar (SD), karena rasa segar dari es batu tersebut ketika dikonsumsi.

Kurangnya perhatian pedagang terhadap faktor kebersihan dalam penanganan es batu menyebabkan tingginya angka kontaminasi mikrobilogis pada es batu 
tersebut. Berdasarkan data dari pentingnya memlihara pangan terutama yang dikonsumsi oleh anak SD, maka peneliti tertarik untuk melihat bagaimana keamanan pangan jajanan es batu pada anak SD sehingga perlu dikaji mengenai keberadaan E.coli di dalam es batu pada jajanan anak Sekolah Dasar di wilayah Kecamatan Antapani Kota Bandung.

\section{BAHAN DAN CARA PENELITIAN}

Jenis penelitian yang dilakukan adalah dengan pendekatan kualitatif, dimana penelitian ini mencakup informasi tentang fenomena utama yang dieksplorasi dalam penelitian, partisipan penelitian dan lokasi penelitian[9]. Pemilihan pendekatan kualitatif dikarenakan penelitian ini lebih mendalami proses yang akan dibuktikan dengan uji laboratorium, pengambilan sampel dilakukan dengan purposive sampling. Purposive sampling adalah teknik pengambilan sampel data dengan pertimbangan tertentu[10].

\section{HASIL PENELITIAN DAN PEMBAHASAN}

Hasil laboratorium pemeriksaan E.coli dalam es batu dapat dilihat pada berikut ini:

Tabel 1. Hasil Pemeriksaan Laboratorium Kualitas Es Batu

\begin{tabular}{ccc}
\hline No. & Nama & $\begin{array}{c}\text { Pemeriksaan Bakteriologis } \\
\text { (E.coli) }\end{array}$ \\
\hline 1 & Pedagang 1 & Negatif \\
2 & Pedagang 2 & Negatif \\
3 & Pedagang 3 & Negatif \\
4 & Pedagang 4 & Negatif \\
5 & Pedagang 5 & Negatif \\
6 & Pedagang 6 & Negatif \\
7 & Pedagang 7 & Negatif \\
8 & Pedagang 8 & Negatif \\
9 & Pedagang 9 & Negatif \\
10 & Pedagang 10 & Negatif \\
11 & Produsen 1 & Negatif \\
12 & Produsen 2 & Negatif \\
13 & Air Baku 1 & Negatif \\
14 & Air Baku 2 & \\
\hline
\end{tabular}

Hasil laboratorium yang terdapat pada tabel di atas menjelaskan bahwa semua sampel air yang diteliti hasilnya negatif baik dari segi pedagang maupun produsen. Keterangan kata sampel di atas merupakan sampel es batu yang di ambil dari para pedagang, sedangkan untuk produsen dan air baku merupakan sampel dari produsen pembuatan es batu. Hal ini sejalan dengan penelitian dari Azzahra Pratidina, Yusniar Hanani Darundiati, Hanan Lanang Dangiran bahwa tidak ada hubungan antara praktik higiene pedagang dengan kontaminasi E.coli pada jajanan SD[11].

Pedagang kebanyakan membeli es batu dari produsen tetapi ada juga yang membuat es batu sendiri. Beberapa menjelaskan bahwa air yang digunakan adalah air ledeng yang dimasak terlebih dahulu dan ada juga yang menggunakan air isi ulang sebagai bahan baku pembuatan es batu.

Penggunaan tempat es batu pedagang dan produsen dalam keadaan bersih tetapi ada beberapa yang terlihat kotor dibagian luarnya. Es batu yang ada didalam tempat es tersebut akan diambil dengan menggunakan alat seperti penjepit es batu atau sendok besar untuk memindahkan es batu dari tempat es ke minuman. Peralatan yang digunakan untuk memproduksi es batu pun dalam keadaan bersih, para produsen sadar betul akan kualitas es batu yang dijual harus memenuhi syarat bahkan tempat es batu seperti kulkas pun merupakan kulkas khusus tidak dicampur dengan makanan- 
makanan lainnya. Hal ini diutarakan oleh dilihat pada tabel berikut: produsen 1 dan 2. Hasil wawancara dapat

Tabel 2. Hasil Wawancara mengenai Peraturan Pemerintah terkait Es Batu

\begin{tabular}{clcc}
\hline No. & \multicolumn{1}{c}{ Peraturan } & Tahu & Tidak Tahu \\
\hline 1 & Es Batu & $0 \%$ & $100 \%$ \\
2 & Air Minum & $100 \%$ & $0 \%$ \\
\hline
\end{tabular}

Terdapat $100 \%$ informan tidak mengetahui tentang peraturan es batu secara khusus, akan tetapi $100 \%$ informan tersebut lebih mengetahui mengenai peraturan air minum yang memenuhi syarat.

Tabel 3. Hasil Wawancara Mengenai Sanitasi Pedagang dan Produsen Es Batu

\begin{tabular}{clcc}
\hline No. & \multicolumn{1}{c}{ Sanitasi } & Ya & Tidak \\
\hline 1 & SAB & $100 \%$ & $0 \%$ \\
2 & SPAL & $70 \%$ & $30 \%$ \\
3 & Sampah & $100 \%$ & $0 \%$ \\
4 & CTPS & $10 \%$ & $90 \%$ \\
5 & Baju Kerja & $100 \%$ & $0 \%$ \\
6 & APD & $0 \%$ & $100 \%$ \\
\hline
\end{tabular}

Dilihat dari tabel di atas, Sumber Air Bersih, sampah dan baju kerja sudah $100 \%$ dalam keadaan memenuhi syarat. Untuk SPAL hanya $70 \%$ saja yang menggunakan septictank sementara $20 \%$ sisanya mengalirkan limbah ke sungai melalui saluran-saluran air. Sementara itu hanya $10 \%$ pedagang yang melakukan Cuci Tangan Pakai Sabun (CTPS) dan untuk penggunaan APD tidak satu orangpun pedagang menggunakan APD saat berdagang seperti penggunaan sarung tangan.

Observasi secara umum merupakan proses pengamatan dan pencatatan secara sistematis mengenai gejala-gejala yang diteliti[11]. Selama melakukan wawancara kepada informan, dilakukan juga observasi sekitar lingkungan informan tersebut. Hasil dari observasi dapat dilihat pada tabel berikut:

Tabel 4. Hasil Observasi Penelitian mengenai Es Batu

\begin{tabular}{clcc}
\hline \multirow{2}{*}{ No. } & \multicolumn{2}{c}{ Observasi } & \multicolumn{2}{c}{ Jumlah } \\
& \multicolumn{1}{c}{ Ya } & Tidak \\
\hline 1 & Tumpukan sampah disekitar tempat & $10 \%$ & $90 \%$ \\
& berjualan/produksi & & \\
2 & Tempat penyimpanan es batu dalam keadaan & $80 \%$ & $20 \%$ \\
& bersih & & \\
3 & Kuku penjamah dalam keadaan bersih & $50 \%$ & $50 \%$ \\
4 & Lap yang bersih & $100 \%$ & $0 \%$ \\
5 & Jamban sehat & $80 \%$ & $20 \%$ \\
6 & Menggaruk kepala lebih dari 3 kali & $0 \%$ & $100 \%$ \\
7 & Penggunaan sarung tangan & $0 \%$ & $100 \%$ \\
8 & Alat mengambil es batu dalam keadaan bersih & $90 \%$ & $10 \%$ \\
\hline
\end{tabular}

Hasil yang didapatkan pada tabel diatas dapat dilihat bahwa yang mencapai angka $100 \%$ atau semua informan melakukan hanya dalam kategori lap saja. Sisanya harus lebih ditingkatkan lagi.
Didapatkan hasil dari uji laboratorium bahwa semua es batu yang didapatkan dari produsen dan pedagang es batu yaitu negatif mengandung E.coli. Berarti dalam hal ini sumber air untuk pembuatan es batu tersebut sudah 
merupakan air yang layak minum sehingga untuk sumber air dinyatakan negatif. Begitu pula dengan sanitasi pedagang, hasil yang didapatkan semua negatif atau dinyatakan tidak mengandung E.coli maka secara otomatis sudah dapat dipastikan sanitasi pedagang tersebut juga negatif. Jadi jika hasilnya negatif E.coli, maka sumber air dan sanitasinya sudah pasti negatif.

Kadar E.coli dalam air harus 0 per 100 mililiter air, apabila tidak ditemukan E.coli maka air minum tersebut secara mikrobiologis dinyatakan tidak tercemar[12]. Semua sampel yang menjadi objek penelitian dinyatakan memenuhi syarat dimana kadar E.coli pada semua sampel 0 per 100 mililiter air.

Berdasarkan hasil wawancara kepada pihak Sekolah Dasar dikatakan bahwa tidak ada sanksi atau kebijakan khusus untuk pedagang yang nakal dengan kata lain menggunakan bahan-bahan yang tidak layak untuk dikonsumsi. Pihak sekolah hanya memberikan peringatan secara ringan kepada para pedagang, seperti memperingatkan untuk mengganti bahan yang tidak layak konsumsi menjadi bahan yang layak konsumsi. Berdasarkan hasil wawancara dengan Dinas Kesehatan bagian Kesehatan Lingkungan dikatakan bahwa tidak terdapat peraturan secara khusus untuk penjual es khususnya es batu.

Bahan baku pembuatan es batu yang digunakan oleh produsen ada dua jenis yaitu yang berasal dari PDAM dan berasal dari air minum isi ulang. Namun untuk membersihkan peralatan pembuatan es batu dibersihkan dengan menggunakan air dari PDAM. Berdasarkan hasil penelitian ini didapatkan hasil bahwa untuk kandungan E.coli pada es batu dinyatakan negatif, yang artinya bahan baku es batu tersebut sudah memenuhi syarat.

Penggunaan Sumber Air Bersih yang ada di pedagang juga menggunakan air PDAM, air ini digunakan untuk MCK seperti mencuci tangan, mencuci peralatan ketika berada dilokasi berjualan, seperti gelas. Peralatan-peralatan lain yang telah selesai digunakan akan dibersihkan di rumah pedagang seperti tempat penyimpanan es batu, sendok untuk mengambil es batu, serta peralatan lainnya. Berdasarkan hasil yang didapatkan dalam penilitian ini, untuk masalah sanitasi pedagang masih belum $100 \%$ memenuhi syarat. Terdapat $100 \%$ pedagang yang masuk dalam kategori untuk kebersihan tempat penyimpanan es batu, hanya terdapat $80 \%$ saja yang memenuhi syarat dan $20 \%$ masih belum memenuhi syarat. Hal tersebut dilihat dari hasil observasi dilapangan dengan melihat secara fisik kebersihan tempat penyimpanan es batu di pedagang jajanan Sekolah Dasar. 20\% yang belum memenuhi syarat ini jika dibiarkan begitu saja tidak diperhatikan maka secara berangsur-angsur akan menjadi masalah karena dapat mempengaruhi yang lainnya. Dalam prosesnya sudah memenuhi syarat hanya saja $20 \%$ yang belum memenuhi syarat tersebut harus menjadi prioritas dalam hal pengawasannya, karena jika terus dibiarkan akan mempengaruhi faktor-faktor yang sudah memenuhi syarat Berdasarkan penelitian yang dilakukan kualitas es batu yang ada dipedagang sudah memenuhi syarat, dilihat dari hasil laboratorium yang menyatakan hasil negatif. Dapat dinyatakan bahwa hasil negatif didapatkan karena air untuk bahan baku dan sanitasi pedagang serta produsen sudah memenuhi syarat.

Pedagang dan produsen dalam penelitian ini dalam kehidupan sehari-hari menggunakan air PDAM, jarak yang aman antara sumber air dengan resapan harus lebih dari 11 meter.

Di wilayah Antapani untuk masalah SPAL masih belum memenuhi syarat dimana masih banyak masyarakat membuang limbah ke selokan atau tempat aliran air yang bermuara ke sungai. Dalam penelitian ini terdapat $70 \%$ informan menyatakan sudah menggunakan septictank sebagai tempat pembuangan sementara $30 \%$ informan menyatakan membuangnya ke sungai.

Sampah harus bebas dari leachate yang merupakan zat pencemar yang 
sangat berbahaya karena karakteristiknya yang mengandung kadar organic yang tinggi bahkan tidak jarang mengandung kadar logam berat. Leachate dapat diartikan juga sebagai cairan yang menginfiltrasi melalui tumpukan sampah[13].

Pengawasan kepada pedagang jajanan sekolah dilakukan oleh Dinas Kesehatan dan Puskesmas. Pengawasan kepada para pedagang jajanan dilakukan oleh Dinas Kesehatan kepada para pedagang hanya memiliki jadwal sekali dalam setahun. Pengawasan ke pedagang jajanan juga dilakukan oleh Puskesmas setiap 6 bulan sekali. Puskesmas melakukan pengawasan atau pemantauan ke pedagang jajanan tidak ditemani oleh pihak Dinas Kesehatan. Dinas Kesehatan hanya memberikan perintah yang kemuadian akan dilaksanakan oleh pihak Puskesmas.

Sarana prasarana yang digunakan dalam pembuatan es batu ada 2 , ada yang menggunakan mesin dan ada yang menggunakan cara tradisional. Es batu yang menggunakan mesin dimana bahanbahan yang digunakan untuk membuat es batu sudah menjadi satu kesatuan dalam mesin tersebut sehingga es batu yang dihasilkan sudah berbentuk Kristal dan siap disajikan. Berbeda halnya dengan pembuatan es batu secara tradisional, alatalat dari mulai air baku sampai pengemasan menggunakan tenaga manusia, bahkan ada yang hasilnya masih dalam bentuk bongkahan es yang sebelum dikonsumsi dilakukan pemecahan es menjadi serpihan yang lebih kecil.

Dalam prosesnya baik pembuatan es batu maupun proses distribusi es batu sudah sesuai dengan kaidah kebersihan tetapi berbeda halnya dengan sarana prasarana, masih ada yang belum memenuhi syarat seperti yang sudah dijelaskan di atas, terdapat $20 \%$ tempat penyimpanan es batu yang belum memenuhi syarat dari keseluruhan target pencapaian. Hal ini perlu menjadi prioritas dan perhatian lebih oleh tenaga kesehatan untuk dapat memberikan penyuluhan tentang kebersihan, karena jika 20\% ini dibiarkan maka akan mempengaruhi 70\% yang sudah memenuhi syarat.

\section{KESIMPULAN DAN SARAN}

Air yang menjadi bahan baku untuk pembuatan es batu di produsen dinyatakan negatif mengandung E.coli, produsen es batu rumahan kebanyakan lebih memilih untuk menggunakan air isi ulang sebagai bahan baku pembuatan es batu menggunakan air isi ulang tidak usah direbus dan menghemat waktu produksi, bahan baku yang negatif E.coli ini ternyata juga berpengaruh pada es batu yang sudah selesai diproduksi. Para produsen menggunakan alat-alat pembuatan es batu yang bersih, seperti kresek yang digunakan untuk memproduksi es batu disimpan dalam wadak tertutup dan untuk kulkasnya digunakan kulkas khusus membuat es batu yang tidak dicampur dengan penyimpanan bahan makanan lain. Pedagang yang menggunakan tempat penyimpanan es batu, sebanyak 20\% belum memenuhi syarat. Dalam prosesnya pedagang yang belum memenuhi syarat harus menjadi prioritas untuk pengawasan karena dapat memengaruhi faktor-faktor yang sudah dalam keadaan memenuhi syarat. Berdasarkan hasil laboratorium diketahui bahwa keberadaan E.coli dalam es batu yaitu negatif, maka dapat dikatakan bahwa air yang digunakan sebagai bahan baku dan sanitasi produsen dan pedagang sudah memenuhi syarat sehingga es batu dalam keadaan layak minum.

Meningkatkan pengetahuan pedagang mengenai sanitasi melalui penyuluhan oleh tenaga kesehatan baik dari Puskesmas maupun Dinas Kesehatan serta dapat juga dilakukan oleh guru UKS dari pihak Sekolah Dasar.

\section{KEPUSTAKAAN}

1. WHO 1997. (2011). Guidelines For Drinking-Water Quality $4^{\text {th }}$ edition.

2. Dieter, H. H. (2014). Related Guide Values For Drinking Water Since 1993.

3. WHO 1997. (1998). Guidelines For Drinking-Water Quality $2^{\text {nd }}$ edition.

4. Estiasih, T., Ahmadi. 2009. Teknologi Pengolahan Pangan. Jakarta: Bumi Aksara.

5. Winarsih, S. 2009. Pengetahuan Sanitasi Dan Aplikasinya. Jakarta: Aneka Ilmu. 
6. "Waspada Bahaya Es Batu”. (2009) (http://www.wartawarga.gunadarm a.ac.id/diakses 12 Januari 2018).

7. Melliawati, R. (2009). Escherichia Coli Dalam Kehidupan Manusia. BioTrends, Vol.5, No.1.

8. Permenkes No.492/Menkes/Per/IV/2010 tentang Persyaratan Kualitas Air Minum

9. Jay, J. (2000). Modern Food Microbiology sixth Edition. Gaithersburg, Maryland: Aspen.

10. Rifta, R., Budiyono., Darundiati, Y.H. (2016). Studi Identidikasi Keberadaan
Escherichia coli Pada Es Batu Yang Digunakan Oleh Pedagang Warung Makan Di Tembalang. Jurnal Kesehatan Masyarakat, Vol.4 Nomor.2.

11. Dinas Kesehatan Kota Bandung. (2012). Profil Kesehatan Kota Bandung.

12. Riyanarti, M.M. (n.d.). Keamanan Makanan Dan Jajanan. Retrieved from http://www.nanopdf.com/ diakses 25 Januari 2018.

13. Sugiyono. 2016. Metode Penelitian Kuantitatif, Kualitatif dan $R \& D$. Jakarta: Alfabeta. 
